\title{
Opportunities for Listening and for Instruction that Occur During the Learning Process
}

\author{
Sariani \\ English Department, State Polytechnic of Padang \\ sarianipasni@yahoo.com
}

\begin{abstract}
Teaching a language whether English for Foreign Language (EFL) or English as a Second Language (ESL) always focuses on the four skills: listening, speaking, reading and writing and should have applied into a well-balanced implementation to each. Highlighted by Nunan (1998) that over $50 \%$ of the time spent by the students is for listening in learning a foreign language therefore it plays significant role in language development. The complexity occurs when the teaching-learning process is lack of adequate attention on improving their listening skill rather than testing their comprehension. Therefore by applying principles of 'Meaning, Interesting, New Language, Understanding, and Stress-free (MINUS)' might assist the teachers to come up with sufficient techniques to make the students can easily engage and obtain language items. Opportunities are discussed which may lead to a more productive learning time in listening by providing attractive variation of teaching. The desired outcomes for both principles and points of approach can accommodate teachers to develop their students listening skill as has been set in their lesson plan.
\end{abstract}

Keywords-MINUS, principles, points of approach

\section{INTRODUCTION}

English as lingua franca is totally needed for one who wants to be the citizen of the world and to be success both academically and professionally not only within the country but also world-wide. Therefore, English is also taught in Indonesia as one the foreign language (EFL) subject in formal schools starts from the Junior High School to the Higher Institution. State Polytechnic of Padang (PNP) as one of the higher institution in Padang, West Sumatera, Indonesia takes English among other subjects taught as the compulsory one as well. The students learn it since their fresh year to the last year of their study. The institution puts some expectations for its graduate students that they are not only competent in their own background's major but also proficient enough in communicating with foreigners by using English.

As a matter of fact, there are some students to mention who still feel that they are not fluent in communicating with English. It is perhaps either the lack of their self-confident due to their limited knowledge and practice or initially blocks themselves from learning. Commonly they say that English is a difficult lesson to be learned.
Nevertheless, there is a few of them who is capable or can be said fluent spoken and written in English even though it is limited in numbers.

Despite the lack of qualified and advanced language laboratory, internationally high qualified books of English lesson, cannot be the reasons for these students to not learning it creatively. There are many other sources that they can find from out of the class environment such as from the internet, television programs, etc.

Indeed, it is such a complex matter of learning English in an institution as it involves other stakeholders: the institution, the lecturers and the student themselves. Thus, observation and investigation are needed for a preliminary analysis of this handicap so that the solution could be reached. Basically, in learning the three parties of these stakeholders must be cooperated among them in order to perceive a good result. Thus, it should be taken into account that changes may occur over time as students more or less spend their time in learning and come up with other ways to develop their skill and knowledge of English. 


\section{A. Problem}

The context is fresh year students at PNP, who are considered in the level of general English for their English knowledge. One class usually consists of 25 to 30 students, and they mainly spend the teaching-learning for 90 minutes in once a week. The learning that has been designed by the lecturer mostly the combination of the four skills in English: listening, reading, speaking and writing. Though yet an equal balance applied for each of the four skill.

Apparently, the designed time for the English class yet fulfils the needs of the learners to fully master it. Thus, the ability of each lecturer in managing their classroom is significantly required. There are many kind activities that they can implement in their classroom, particularly for the listening part. The approach used by the lecturers in establishing their classes counts the result achieved from the students' performance. Commonly the lack of self confident from the students and/ or lack of knowledge of how to approach listening in the real world is because the wrong method applied. Mostly the lecturers tend to focus on testing their comprehension whereas what the students need is on how to improve their listening skills.

Regarding to this matter, it comes to mind the appropriate learning opportunities for this listening class that can occur during the learning process. Indeed, these opportunities are those that can ease the burden of the lecturers and help the learners to engage and to understand the materials being taught.

\section{B. Objective}

To a considerable extent, English is taken as significantly useful for the higher institution's students. One of the benefits of being fluent in English is to help them in competing for the job adequate job vacancy. Therefore, the objectives are addressed to the three parties involved in the teaching-learning process; the students, the lecturers, and the institution. The students can develop their knowledge of English as they can engage during the teaching learning process, particularly the listening class. Besides that, the outcome of this analysis can also provide them easier way to acquire English by giving them learning opportunities which indirectly can motivate them in learning.

In addition, the lecturers can also provide varied opportunities for teaching listening in order not to make the students to be easily bored and lack of attention in learning. Meanwhile the objective for the institution, it can produce graduate students who are not only capable with the knowledge of their academic background but also skilled in communicating with English.

\section{Significance of the Study}

The desired output is meant for two out of the three parties, i.e; the students, and the lecturers. It is expected that the lecturers can accommodate possibilities and/ or alternative methods for students to learn and to develop their English knowledge. Besides that, these opportunities can enhance the ability of the lecturer to implement their teaching technique in order to achieve the result which has been set in their lesson plan.

Regarding to this matter, the lecturers can come up with adequate support for the students to apply the 'Meaning, Interesting, New Language, Understanding, and Stress-free (MINUS)' principles so that they can easily engage and obtain language items and patterns of English. By having this support they can be more motivated in learning and developing their English and to be fluent in it since the lesson become more interesting for them to be learned.

Referring to the question and the goal mentioned above, the hypothesis of the analysis is hot to empowering the opportunities of learning English, particularly the listening skill. As there are attractive variations of teaching and learning techniques applied, there is a good chance for the students to develop their knowledge and skill of this language as well.

\section{LITERATURE REVIEW}

\section{A. Learning a Language}

Basically, each of us has innate ability to acquire languages through sufficient input and 
exposures. Nevertheless, there are some who have learned foreign languages for years, but often feels that they are not fluent as a user of the language. Therefore, learning a language is necessary for those who want to be adequately fluent speaker of the language since learning requires consciously participation from the learner to study the rules and patterns of the language (Parrish, 2004).

A language is learnt when people want to communicate to each other easily without any barrier which could result to misunderstanding. Parrish (2004) states that communicative competence means the ability of someone to apply varieties of language setting such as at work, at store, etc with varied degree of formality. Therefore to be able to be communicatively competence in such a language, a learner should become proficient in a number of areas of that language. The ability to make someone else understands of the message that they want to convey is in the same balance with the ability to produce grammatically correct sentences. According to Parrish (2004) there are areas of a language that one should learn in order to communicate well with others. They are language forms, social interactions, language skills and language strategies.

TABLE I

AREAS OF LANGUAGE

\begin{tabular}{|c|c|}
\hline $\begin{array}{l}\text { Language Forms } \\
\text { (Linguistic } \\
\text { Competence) }\end{array}$ & $\begin{array}{l}\text { Knowledge } \\
\text { grammatical forms, } \\
\text { spelling, vocabulary, } \\
\text { and pronunciation. }\end{array}$ \\
\hline $\begin{array}{l}\text { Social } \\
\text { Interactions } \\
\text { (Sociolinguistic } \\
\text { Competence) }\end{array}$ & $\begin{array}{l}\text { Ability to use language, } \\
\text { both verbal and } \\
\text { nonverbal, appropriately } \\
\text { in social contexts. }\end{array}$ \\
\hline $\begin{array}{l}\text { Language Skills } \\
\text { (Discourse } \\
\text { Competence) }\end{array}$ & $\begin{array}{l}\text { Ability to read, write, } \\
\text { understand, and use } \\
\text { spoken language. }\end{array}$ \\
\hline $\begin{array}{l}\text { Learning } \\
\text { Strategies } \\
\text { (Strategic } \\
\text { Competence) }\end{array}$ & $\begin{array}{l}\text { Ability to use strategies } \\
\text { to make yourself } \\
\text { understood; how to learn } \\
\text { on your own outside the } \\
\text { classroom. }\end{array}$ \\
\hline
\end{tabular}

(Parrish, 2004, p. 9)

Likewise Parrish (2004), Harper (1998, p. 52) states that 'There are four things that students need to do with 'new' language: be exposed to it, understand its meaning, understands its form (how it is constructed) and practice it'. Therefore, in order to learn a language a learner doesn't have to acquire the construction of the language itself, but they also have to practice it for any activity they are engaged.

\section{B. Learning Opportunities}

Nation and Newton (2009) agree that the opportunities for learning a language should be continuously performed. The learning goals are not merely focus on the fluency itself but cover other areas such as grammar, spelling, vocabulary etc. Hence, Nation and Newton (2009) named these learning goals as strands which consist of four and they don't work when they stand alone. Similar thought that been discussed by Nation (2009) about this learning opportunities.

The four strands that they meant are meaningfocused input, meaning-focused output, language-focused learning and fluency development. Each strand differs to the other. The use depends on the conditions which are needed for the different types of learning. The basic idea of these four strands is to have a well-manage language learning, which equally focus on each of the strands.

TABLE II

FOUR STRANDS OF LEARNING

\begin{tabular}{|l|l|}
\hline $\begin{array}{l}\text { Meaning } \\
\text { focused input }\end{array}$ & $\begin{array}{l}\text { Involves getting input } \\
\text { through listening and reading } \\
\text { where the learners focus is } \\
\text { on understanding the } \\
\text { message. }\end{array}$ \\
\hline $\begin{array}{l}\text { Meaning- } \\
\text { focused } \\
\text { output }\end{array}$ & $\begin{array}{l}\text { Involves learners producing } \\
\text { language through speaking } \\
\text { and writing where the } \\
\text { learner' focus is on others } \\
\text { understanding the message. }\end{array}$ \\
\hline $\begin{array}{l}\text { Language- } \\
\text { focused } \\
\text { learning }\end{array}$ & $\begin{array}{l}\text { Involves deliberate attention } \\
\text { to language features both in } \\
\text { the context of meaning- } \\
\text { focused input and meaning- } \\
\text { focused output and in } \\
\text { decontextualised learning } \\
\text { and teaching. }\end{array}$ \\
\hline
\end{tabular}




\begin{tabular}{|l|l|}
\hline $\begin{array}{l}\text { Fluency } \\
\text { development }\end{array}$ & $\begin{array}{l}\text { Involves making the best use } \\
\text { of what is already known. }\end{array}$ \\
\hline
\end{tabular}

(Nation, 2009, p. 1,2)

In order to have a well balanced learning opportunities in learning a language, it is suggested to have roughly the same amount of time for each strand. The purpose behind is to make the best use of receptive and productive skills of a learner.

\section{Listening Skill}

Listening plays an important role in language development either it is in its first language or second language (Nunan, 1998). He says that over $50 \%$ of the time spent by the students for listening in learning a foreign language. It is because listening is the natural precursor to speaking (Nation and Newton, 2009). Millin (2014) agrees that listening is the skill that people use most in their second language. One has to understand the speakers who utters different context of topic, and comes from different educational background, gender, age, and accents whether they are native or non-native. However, this is rarely become focus on attention of the teacher in the classroom. It is because they concern more on other students in the class and on scripted course book recordings in 'standard' forms of English.

As a matter of fact, listening can be divided into two types, they are one-way listening, and the second one is two-way listening. One way listening can also be said as traditional listening where the information is being transferred (transactional listening). On the other hand, the two-way of listening is more to how to maintain social relations (interactional listening). Mostly it is used in academic context where the materials are more contemporary (Nation and Newton, 2009).

\section{DISCUSSION}

\section{A. Opportunities for Learning Process}

There are many opportunities that can be done during the learning process in listening. However, before designing which kind of task to be conducted, one should come up with the idea of form of listening process that they want to bring. Listening process can be distinguished into two, i.e; 1) Bottom-up process, and 2) Top-down process.

1) Bottom-Up Process : Bottom-up process is the process when the learner takes parts of the learning bit by bit and then assembles them to have a whole idea (Nation and Newton, 2009).

There are two kinds of activity for proposed learning which are included into bottom-up process; they are 'Information transfer' and 'Listening to stories'.

\section{Information transfer activity}

Mostly during this activity, the lecturer can actively engage the learners with the task given. Thus, the time designed for the class is used properly since the students' time is occupied by working with their task without leaving it wasted.

The activities are:

1. First, a record is played. It is about particular topic that is taken from their workbook. While listening to the tape they are allowed to take a note on words that they know or words that they consider important.

2. Usually, the tape will play three times, for the first time they just listen, the second time, they will be asked to write down relevant information to the question. Then, they fill their answer with the information perceived.

3. Then, pair work's discussion, so they can share their views and understandings to their partner.

4. Finally, class discussion. It is meant for the students to be able to compare their answers and to come up with similar answers for the whole class.

\section{Listening to stories}

The story chosen for this activity should be the material at their level. By having only few unfamiliar or partly unfamiliar words, it helps the learners to easily understand the material. Besides 
that, the right level material also provides possibilities for interaction between the teacher and the learners during the listening process. It happens since the teacher can occasionally asks questions or gets the learners to anticipate the next flow of the story. The learners also can ask the teacher to repeat the story or slow down or explain more on the words by showing their 'not knowing' gesture or deliberately ask the teacher (Nation and Newton, 2009).

The activities are :

1. Initially, a story which has been chosen based on the level of the learners read by the teacher.

2. Most of sentences in the story are read twice and slowly. It is meant to help the learners to analyse the words spoken so that when they encounter unknown words, they can ask the teacher directly either by showing the gesture or ask them deliberately.

3. While reading the story, the teacher sits next to the whiteboard, thus it will be easier for them to write down any unknown words that are needed to be written and explained.

4. When the same unknown words appear to the story, the teacher just has to point on the whiteboard.

Therefore, soon as the learners become familiar with the story and have little unknown words to be understood, then the story can be read a little faster than before.

2) Top-Down Process: Top-down process is when the learner comes from the whole which is their prior knowledge in conducting the task. Nation and Newton (2009, p. 40) state that 'In other words, the listeners use what they know about the context of communication to predict what the message will contain, and use parts of the message to confirm, correct or add to this'. Hence, the key process of this kind of learning process is inference.

There are two kinds of activity for proposed learning listening which is included into bottomup process, they are 'Picture ordering' and 'What is it?'

\section{Picture Ordering}

Instead of using pictures that tell a story, this task arises the students's mind to arrange the pictures based on the story they hear. Once again, the story being read is the one that is at their level which has few unknown words. The picture ordering happens when the learner should arrange the set of pictures which are put in random order while listening to a story. This kind of picture ordering can be found in the comic strips or from other sources which are considered suit their level (Flenley, 1982).

'The activities are:

1. Learners will see a set of pictures that are arrange randomly on the white board or in their work book.

2. Then, while listening to the description of a story, they re-arrange or compose the pictures based on the order of the story that they hear.

\section{What is it?}

Nation (1987) established this activity for early listening and speaking. Here, the learners will hear a description of something. Then they have to decide what is being described based on what they hear. There will be sentences read about the description, begins with a little bit of information and gradually there will be more if the learners are still not able to describe the thing. Soon after the learners can guess what is it, then the teacher will stop read the clue information.

\section{B. Balance Range of Listening Opportunities}

Balanced range that listening opportunities should be aimed to enable students to more comprehend the process of listening. Activities such as questionnaire, stimulated recall, and interviews can provide insight into student's awareness of a process when they are listening (Vandegrift, 2010).

This awareness is significant to the learners because some of them use top-down process that requires context and prior knowledge and some use bottom-up process that requires word segmentation. Word segmentation is hardly to perceive by learners since they have to encounter 
the rapid speech rate that enable them to recognize words or to miss some parts of the text. Thus, aids are needed in order to help the learners to recognize them.

Here, teachers can use pictures, video clips, key vocabulary presentation, class discussion, cultural information or question preview to develop learners' prior knowledge (Vandegrift, 2010). These aids allow the learners to have access to particular topic. As highlighted by Goh (2000), that this existing knowledge is included into parsing phase, one out of three model's phases for comprehension proposed by Anderson (1995). The other two phases are perceptual processing and utilization, where three of them are interrelated and recursive, and might be sometimes overlap in practice.

"The ultimate goal of listening instruction is to help L2 listeners understand the target language in everyday situation (Vandegrift, 2010, p. 199)". It would be benefit for the learners if the listening materials are taken from the real life situation or authentic-type texts. Therefore, texts which approximately close to authentic form of real life situation used by native speaker will help the learners. The difference between beginner level and advance level learners are from the speech rate, but it does not have to adjust to their proficiency.

Furthermore, Nation and Newton (1999) discuss about note taking during the listening task. This activity is an essential skill for learners since it can store information of what they have heard and it gives opportunity for them to encode the information for the later use. There are strategies in note taking highlighted in Nation and Newton (1999), which can be applied by learners and teacher. At first, it should come from the teacher, by giving instruction of how to make a good note taking. Teacher can introduce first, what kind of information to be written down, then, how to take a note from examples.

There are various ways to make a note such as spray diagrams, tree diagrams or ordered list. Third, teacher organizes his/her lectures to enable the students to take a note by having pauses during the lectures. The most important thing that learners should acquire is how to encode those notes that they have made, so that they can comprehend the information that they have gathered.

Referred to the context mentioned in early discussion, the listening task will be easier for those learners if teacher has known what strategy that he/she apply in order to overcome difficulties of the learners. As noted by Newton (2009), " ....once learners and teachers have identified specific listening sub-skills that are causing difficulty, these problems than guide subsequent listening skills and strategy instruction and practice (p. 55)".

It means that when the learners and the teachers can determine what the problem is, then they can develop such strategies or instructions to enable the learners comprehend and engage to the listening task more. Newton (2009, p. 54) proposes opportunity standards for listening tasks, which are; 1) Extensive meaning-focused listening, 2) Guided diagnosis of miscomprehension problems, 3) Listening skills and practice, 4) Listening strategy training, 5) Link to listening beyond the classroom.

\section{Evaluation of Teaching Opportunities}

Mostly the learners in listening class encounter several problems which are noted as well in Goh (2000)'s study. First, they have limited capacity of short- term memory that is when they are easily to forget words that they heard. Second, it is difficult for them to recognize words which are actually familiar to them. It takes time for them to recall the meaning of the words immediately. Third, they understand the words that they heard but they are unable to get the meaning. Thus the five standard opportunities suggested by Nation and Newton (2009) are adequate to establish for listening in this context because they consist of strategies which include perceptual processing, parsing phase and utilization (Goh, 2000).

These standards are a set of learning conditions that should be met for any language development through listening in order to have a comprehensible input. These conditions are represented by the acronyms MINUS. They are :

Meaningful (M) means focus on meaningful and relevant language. 
Interesting (I) means main interest through a variety of activities, the one that attracts learner' attention.

New Items (N) means avoid overloading learners with too much new language.

Understanding (U) means providing plenty of comprehensible input. The learners should be assisted to understand the material.

Stress-free (S) means creating a friendly, safe, cooperative classroom environment in order to control stress and anxiety of the learners. (Nation and Newton, 2009, p. 19)

They help the learners to encounter their difficulties and to develop their listening skill. Since the goal of listening instruction is to develop the second language learners' competence in a day-to-day basis, thus real-world tasks should be replicated.

\section{Options for Enhancing the Teaching Listening}

"There are some obviously pedagogic tasks for which it is possible to create real-life contexts (for example "Listen to an aural text and write a sentence restating the gist.') (Nunan, 1989, p. 41)". The real-life tasks can be listening to a news report either from radio or television. Indeed, this news report should be modified and adapted in some way before they are brought into the classroom.

For example, the news report can be re recorded at a slower pace to accommodate student's proficiency. Before the teacher plays the tape, both teacher and learners brainstorm ideas of the topic to assist the learners. Then the teacher might replay the record for several times before the learners are asked to complete the questions (Nunan, 1989). Yes/ No question is applicable for this news report because they require learners' listening and thinking skills to distinguish true and false inferences. This task can be repeated for several times with different topics as the news headlines.

\section{CONCLUSIONS}

The opportunities for the listening that occur during the learning process as have been discussed previously are considered beneficial for the students. These opportunities can encourage the students to perform well and gain a better understanding of the language learning since they can totally be involved within the activities. Crabbe (2007) highlights that the process of learning on foreign language is often hidden from the students, therefore it is the teacher's role to naming, modelling and encouraging them to manage their own learning independently so they can focus on improving their performance in doing the tasks.

However, to ensure that the opportunities are worked well and the result's is achieved, both the lecturers and the students should have the same work. It can be said that they should balance the work load between both of them and make this learning is not only actively used by the students but also by the lecturers.

\section{REFERENCES}

[1] Crabbe, D. (2007). Learning opportunities: adding learning value to tasks. ELT Journal 61 (2), 117-125.

[2] Flenley, T. (1982). Making realistic listening material. Modern English Teacher 10,2: 14-15.

[3] Goh, C. (2000). A cognitive perspective on language learners' IIstenıng comprenension prodıems. system, Lð (1), כว-ノ.

[4] Harper, J. (1998). How to teach English: An Introduction to the practice of English language teaching. England: Pearson Education Limited.

[5] Nation, I.S.P.(1978). "What is it?" a multipurpose language teaching technique. English Teaching Forum 16,3: 20-23, 32.

[6] Nation, I.S.P. (2009). Teaching ESL/EFL Reading and Writing. New York: Routledge, Taylor and Francis.

[7] Nation, I.S.P. and Newton, Jonathan. (2009). Teaching Listening and speaking. Koutleage: Lonaon.

[8] Newton, Jonathan. (2009). Listening in the Language Classroom. Modern English, 18 (3), 52-58.

[9] Nunan, D. (1998). Approaches to teaching listening in the language classroom. In Proceedings of the 1997 Korea TESOL Conference, Taejon, Korea: KOTESOL.

http://www.kotesol.org/pubications/proceedings/1997/nunan_david.p df (html version) (retrieved 15 November 2007).

[10] Nunan, David. (1989). Designing Tasks for the Communicative Classroom. Cambridge University Press: Cambridge.

[11] Parrish, B. (2004). Teaching Adult ESL. New York: McGraw Hill.

[12] Vandergrift, Larry. (2007). Recent developments in second and foreign language listening comprehension research. Cambridge Journals, 40, 191-210.

[13] http://sandymillin.wordpress.com/2014/04/04/iatefl2014/ 